\title{
初中语文多元化教学模式实践策略
}

田晓佼

重庆市南华中学校

DOI:10.32629/jief.v2i4.1301

[摘 要] 初中生处于学业中非常关键的时期, 承上启下, 而语文课程对初中生的基础更是有直接的影响。新课改下, 教师要改变以往初中语 文课中, 用单一的方法和模式对初中生讲授知识的思路, 而是借助多元化教学, 丰富初中生在初中语文课中的体验和感受, 营造出更加轻松 以及丰富的教学氛围, 为初中语文课增加一些色彩和活力。本文分析初中语文课中, 如何开展多元化教学, 希望对提升初中生在初中语文课 中的主动性以及参与度是有一定效果的，减轻教师和初中生在语文课中的压力，促进初中语文课的高效化开展。

[关键词] 初中语文; 多元化; 教学模式; 策略

中图分类号: G633.3 文献标识码: A

初中语文课的教改和实践一直受到广泛重视, 语文课程有着显著的 基础性以及广泛性, 在初中语文课中, 注重对初中基础知识的锻炼以及 语言知识的提升, 从根本上促进初中生语文素养的发展。而在多元化教 学中, 结合初中生的需求, 教师对初中生展开针对性的教学和指导, 可 以让初中生的语言能力得到最大程度发展, 并丰富初中生的学习领域。

因此教师要对多元化教学加强重视, 提升初中生的全面素质。

\section{1 初中语文多元化教学的作用}

初中语文课中开展多元化教学, 就是实现教法和课程内容的多元化, 让初中语文课的课程内容更加丰富, 并以初中生的兴趣爱好作为主要参 考对象, 对初中生的能力展开全方位锻炼和提升。在实际教学中, 要结 合初中生的特点以及初中语文课的课程目标, 借助多样化的方式, 增强 初中生对课程的热情以及主动性。初中语文课注重思维方面的训练和提 升, 并通过阅读理解的方式, 强化初中生的语言能力。在其中有很多的 学习难点, 不容易进行理解以及贯彻。借助多元化教学, 可以对实际入 手, 对学习思维进行拓展, 为初中生提供更广阔的学习空间以及创造就 会, 从而促进初中生能力的多元化发展, 尤其是学习能力的提升, 对初 中生的日后发展有着非常重要的现实意义。

\section{2 初中语文课教学模式中存在的主要问题}

2.1 初中语文课的教学效率不高

初中语文课的开展, 要注重知识在实践中的有效利用。语文本身是 语言学科, 有着非常重要的实践价值。在日常交流中语言是重要工具, 可以看出课程的实践性。但是在现阶段的初中语文课中, 多数的教师注 重对初中生进行理论知识的灌输, 满足初中生考试升学的需求, 忽视了 课程本身的实践性。教师会围绕着考点以及教学任务, 对初中生照本宣 科地讲解完书本上的知识, 忽视了多元化以及实践性教学手段, 其实这 种模式的效率以及初中生在语文课中的接受度并不是非常高, 让初中语 文课的开展受到一定的阻碍。

\section{2 初中生总是处于被动}

新课改下, 初中生应该是课堂中的主体, 教师要将自己放在辅助和 引导的位置上。这种倡导已经说明了, 高效学习是主动的过程, 学生本 身要对课程有非常强的主动性以及积极性, 这样教学才会更加理想。然 而多数的教师注重在初中语文课中, 为初中生传授知识, 满足初中生升 学和考试的需求, 忽视了初中生本身对学习的主动性。多数初中生已经 习惯了这种被动, 对教师有着极强的依赖性。对语文学习不主动, 也很 少进行主动思考, 创造性思维明显不足。这样导致初中生无法在初中语 文课中表现自己, 课堂的效率也不断降低。

\section{3 初中语文课中多元化教学模式的策略}

3.1 构建多元化的课堂教学模式

初中语文课中开展多元化教学, 教师要考虑到初中生的实际需求以 及兴趣爱好。构建出多元化授课的模式, 是实现多元化教学的一个前提。 初中语文课中的教学任务, 主要是课本学习以及写作训练。初中生的语 文能力, 需要在初中语文课中逐渐掌握。在实际授课中, 教师要借助多 样化的方法, 为初中生营造出非常轻松的氛围以及环境, 将初中生的热 情点燃。学习氛围直接影响到初中生在初中语文课中的情绪以及学习效 果。所以教师要借助对各类手段的利用, 将学生情绪调动起来。比如可 以借助多媒体技术, 为初中语文课准备精彩的课件, 将一些课程内容用 生动的方式, 对初中生进行展示。这样初中生就会形成非常强的积极性, 对初中语文课具备更高的参与度, 同时借助多元化教学的合理开展, 对 初中生的思维以及自学能力进行锻炼。

3.2 多元化监督和评价

对初中生展开监督和教学评价, 可以观察以及巩固初中生对初中语文 课的学习成果, 是教师对初中生学习情况进行了解的方式, 也是对教学策 略做出调整的一种依据。以往教师对初中生进行评价, 主要的方式就是考 试, 通过考试成绩, 另加初中生学习的好和坏。但其实监督和评价也可以 用多样化的手段, 实现对初中生有效的激励。比如教师可以借助新媒体的 功能, 对初中生的自主学习以及语文阅读展开监督, 让初中生每天保持课 外的阅读, 并将自己的学习情况上传到班级群。也可以借助小组合作机制, 让小组内的成员实现相互监督, 提升初中生的学习动力。

\section{4 结论}

总之, 初中语文课中, 教师要善于借助多元化教学, 提升初中语文 课授课的实效性。

\section{[参考文献]}

[1]张贤志.迎得春来非自足, 百花千斗共芬芳——苏州吴中区迎春中 学金复耕校长访谈[J].教育视界,2018(21):68-70.

[2]陈广团. 生活化理念下初中语文课堂教学的本色追求一一由董旭 午执教《爱莲说》谈开去[J].中学语文教学参考, 2018(29):23-25.

[3]张雨晨. 初中语文课堂现代文阅读教学的三种模式研究——以鲁 迅的小说《故乡》《孔乙已》为例 [J]. 读与写(教育教学刊),2018, 15(09):71-72.

[4]奕力娜, 许采娟, 周博. 群文阅读在初中语文课堂教学中的应用研究 ——以朱自清《春》为例[J].科教文汇(下旬刊),2018(07):97-98. 